\title{
Uniform Market Conditions in Road Freight Transport
}

\author{
Patrícia Šimurková $^{*}$, Miloš Poliak ${ }^{1}$ and Salvador Hernandez ${ }^{2}$
}

${ }^{1}$ University of Zilina, Department of Road and Urban Transport, Univerzitna 1, 01026 Zilina, Slovakia; Email: patricia.simurkova@fpedas.uniza.sk,milos.poliak@fpedas.uniza.sk

${ }^{2}$ School of Civil and Construction Engineering, Oregon State University, Corvallis, Oregon, USA; Email: sal.hernandez@oregonstate.edu

\section{*Corresponding Author: Patrícia Šimurková}

\begin{abstract}
International road transport is a specific service within the frame of services provided in the European Union. It is because the conditions of being active on the market are influenced by the states where businessmen operate, but services can be provided throughout the whole year in other member states of the European Union. The aim of the contribution is to highlight the existing problems in international road freight transport sector. These problems persist despite the fact that market access was exempted from the national law of individual member states and regulated directly by EU regulations. The contribution identifies the factors that deform the equal operating conditions in single market.
\end{abstract}

Keywords: Market, road transport, unification, conditions

\section{Introduction}

The EU seeks to harmonize the conditions in road freight transport market, so the carriers would have the same conditions to access the market and operate there regardless of their country registration. For this reason, since 1985 the authority to establish market access rules for road freight transport has gradually moved to the EU level [1]. The transfer of member states' competence to this level has increased during the period of preparation for the opening of the EU single market in 1993.

In the first stage, the market access was regulated by EU directives, however their application into national law did not create the same market access conditions for all carriers. The EU regulations were adopted in 2009 and are effective from 2011. They regulate the access to the road freight transport market across the EU. Together with the harmonization of market access the deregulation of national restrictions occurred. These restrictions have been used before in the form of transport permits [2]. The deregulation of road freight transport caused several problems in the market, mainly due to the delay in tax harmonization and labor law of individual member states [1]. 
The deregulation of the road freight transport market across the EU, while maintaining national competencies in the field of taxation and social affairs created a situation in the road freight transport market characterized by an unfair competitive environment.

The problem of the road freight transport market is not only the different tax burden on carriers operating on the same markets [3]. Another problem is connected with different requirements of drivers concerning social sphere. It leads to a significantly higher fluctuation of drivers compared to other sectors of economy [4]. The aim of the contribution is to identify the factors that cause a lack of competitive environment in the road freight transport business in the EU and also provide the answers to the questions: Is it possible under current EU conditions to harmonize social conditions? What impact would this harmonization have on business environment?

\section{Undesirable Effects in the Road Transport Business}

Road freight transport, the EU market access has deregulated gradually since 1985. According to the judgement of the European Court of Justice1, the requirements for freedom of providing services include the elimination of any discrimination towards a service provider in connection with his nationality, or the fact that he resides in other state than in a state where a service is provided. In 1996, Council Directive No. 96/26 / EC2 was adopted. Given that the Directive allows a possibility of different approaches to its implementation among member states, Council Directive No. 96/26 / EC did not achieve required harmonization of market access. Directive is binding with regard to the result that should be achieved by each member state, whereby a choice of forms and means is left to the national authorities [5].

In 2009, Regulations (EC) No. 1071/2009 and 1072/2009 which uniformly regulate access to the road freight transport market were adopted. The regulations are effective from December 4, 2012. The Regulations clearly define the way to access the profession of road freight transport entrepreneur by defining the professional knowledge that must be possessed by the road freight transport entrepreneur. The Regulation requires member states to adopt implementing national rules governing the technical access procedures to the market under the conditions of a particular country [6]. On the basis of the above analysis, it can be concluded that there was a harmonization of conditions in terms of market access. A carrier who meets the conditions of access to the market under Regulation (EC) No 1071/2009 can apply for a Community license. On the basis of this license the carriers can carry out the road freight transport within the EU member states without restrictions. Under certain conditions, cabotage transports can also be carried out [7].

In liaison with the harmonization of market access, the requirements for harmonizing conditions in the tax area have not been implemented. In addition to tax differences, there are 
notable differences in terms of work: wages, driver productivity, working hours, the way how it is calculated and the corporate structure varies significantly in individual member states [1]. The maximum weekly working time in Belgium is 48 hours, in Portugal 56 hours, in Slovakia, Germany, France and Italy 60 hours, in the Netherlands 64 hours, in the UK and Sweden 68 hours and in Spain70 hours - not to mention all occasional adjustments which allow different working arrangements and more or less frequent aids connected with overtimes and operations that only increase these differences. Working time, overtime work, rest, paid annual leave and social protection systems are still set at national level, which also widens the gaps in unifying conditions.

The phenomenon of unification of market access without harmonizing conditions in the social and tax spheres has caused a number of undesirable effects in the road transport business. At this time, it is possible to identify the side effects that are mentioned in the following part of this contribution.

\subsection{Subcontracting in Road Freight Transport}

Lately, many single-member transport companies without additional staff have been registered. They operate either own or external truck. In fact, the creation of small structures makes it very easy to circumvent the restrictions imposed by national tax and social regulations [8]. In general, within the context of a strong economic competition in the EU, the use of illegal "self-employed" workers is so high, that it has become characteristic of the road freight transport sector7. Subcontracting transport services subsequently causes a spiraling decline in prices in industry [8]. The transfer of responsibility for the social area to self-employed workers often causes the circumvention of requirements of Regulation (EC) 561/2006 that regulates maximum driving times and minimum rest periods for drivers. The transfer of responsibility from large companies to small carriers - selfemployed persons reduces the effectiveness of inspections, because in the case of inspection in large companies a controller has a possibility to inspect several drivers in one inspection. For small companies, only one driver is inspected during a company inspection. Given that EU legislation set the minimum number of hours worked by drivers which the controllers are required to inspect, the situation arises that controllers are motivated to inspect in larger companies.

\subsection{Employment of Drivers from Central and Eastern}

The shortage of freight transport drivers is a persistent phenomenon across the EU. This fact is connected with an effort to employ the drivers from Central and Eastern Europe, often with an aim to reduce wage costs. The protests of drivers from Western part of the EU have persisted since 
1997. In 1997, truck drivers in 15 EU countries started to protest against the growing and illegal use of drivers from Eastern Europe [1].

Prior to the adoption of Regulation (EC) 1072/2009 Eastern European drivers often carried out illegal cabotage in Western European countries. The peak of illegal employment in road freight transport in the EU connected with an insufficient harmonization of social conditions is the case of Willi Betz. It was a transport company that operated more than 4500 trucks in total. The company relied on gaps in road controls on the EU's roads. This activity took place as follows: a parent company based in Germany and its subsidiaries in Austria owned a large number of trucks and therefore CEMT licenses, but only a few EU drivers. They gathered surplus vehicles for which they had official license and provided them to subsidiaries in Eastern Europe, especially in Bulgaria. For example, they employed drivers from Bulgaria - and thus concealed the identity of the actual carrier.

The CEMT report on the assessment of social dumping in profession explains (CEMT, 2002): "Currently, a practical example of the" custom-build "transport activity is a tractor registered in Austria with an Austrian CEMT license, operating in France with a semi-trailer registered in Italy, loaded with Spanish cargo, driven by a driver from Bulgaria or Kazakhstan who speaks the Slavic language and possesses identification documents written in Cyrillic alphabet" [9]. In addition to the country in which the trailer is registered and has all the necessary documents, it is impossible to check whether the driver was actually hired by the tractor owner. Everything that an international company Willi Betz had to do is to make sure that a driver will not drive through Austria. This measure allows the company to employ workers from Eastern Europe, in destinations where the company is in direct competition with EU carriers employing European drivers - it means to be engaged in illegal cabotage.

The competitive advantage in this case was based on the fact that middle and Eastern European drivers offer supply of goods and especially cheap labor. Their average hourly wage is approximately $3 € /$ hour, which represents half to one third of the wages of western European drivers. The competitive effect is enhanced when a company uses two drivers for one vehicle. Willi Betz company was imitated by a number of companies, including at least Kralowetz company. The company was accused of creating poor working conditions for drivers employed from non-EU countries.

\subsection{Creation of Mailbox Transport Companies}

Differences in social and tax laws and regulations across Europe have created competitive disparities that have encouraged and motivated carriers from countries with high taxes to establish a company in Central and Eastern Europe without changing their operations. Companies have 
therefore started to be established in countries where social conditions were more flexible and it was possible to escape from the application of national rules concerning their employees. This process was called the so-called a box-office effect in which, for example, German workers fall under Slovak law only through this legal trick.

The creation of mailbox transport companies was mainly influenced by France and Germany, the two largest transit transport markets in Europe. For this reason, Germany and France are looking for their own solutions to influence the undesirable effects of insufficient harmonization in the economic and social spheres. During 2016 and 2017, Germany, France and Austria started to apply the directive on sending workers concerning the provision of the service to the profession of driver as well. However, the application of this Directive creates significant administrative costs for carriers.

\section{Is There a Solution for Social Harmonization in Road Transport?}

Before 2004, carriers in Western Europe pointed to the risk of harmonizing the road freight transport market without harmonizing conditions in social area. An opportunity to employ a driver from Central and Eastern Europe has caused a distortion of the competitive environment in the road freight transport sector [1]. An importance of distortion of competitive environment became meaningful, when manufacturing companies started to use the just-in-time method which significantly reduced their stock and the associated storage costs. This increased the use of freight transport and number of supplies between companies. The use of trucks began to increase and an emphasis was placed on carriers in terms of the quality of services, especially speed and reliability [10]. New conditions on the market led to an increased share of night work in the driver's weekly working time and it also changed the drivers' willingness to perform the profession of a driver under particular wage conditions. Employment of drivers from Eastern and Central Europe is connected with a survey conducted in 2000. It showed that the most illegal workers in the EU were employed in construction and road transport. The wages of these employees are often lower than the average wage level in country. The aim of the European Commission concerning the EU enlargement in 2004 was a requirement that the candidate countries should catch up with the countries of Western Europe in terms of wages and social legislation through integrating into the European Union and by complying with Community requirements and EU regulations. It insisted on the fact that the social models should be consolidated through enlargement, as in the case of Spain and Portugal. In particular, harmonization of wages in the field of road transport is specific because carriers offer transport throughout the whole European Union market. Every carrier established in the European Union and with a license issued by the Community has the same access to this market. Individual 
states put pressure on increase of wages in international road transport with the use of national regulations in order to reduce the competitive pressure of lower prices of carriers located in the central and eastern parts of the European Union.

Regarding the remuneration of drivers, we conducted a research of drivers' compensation in selected transport companies. The research was conducted from January to March 2017 and the drivers of transport companies from 10 different EU states participated on it. Overall, drivers from 310 transport companies took part in the research. The countries were chosen so that in the research were the states which uphold the introduction of a minimum wage for the work of international road transport drivers (Germany and Austria), Western European countries which incline to a certain protection of the transport market (Belgium, Denmark, the Netherlands, Luxembourg, Italy) and the countries of the central and eastern part of the European Union which are against the unification of the minimum wage across the EU (Czech Republic, Poland, Slovakia) [11].

In the research, the drivers responded to the form of remuneration and the amount of remuneration which appertain to them. The drivers were divided into groups according to whether they are remunerated with a monthly or hourly rate. On average, the highest hourly wage rate is reached by drivers in Luxembourg, it is $15.875 € /$ hour (Tab. 1). By the rates above $€ 10 /$ hour are also remunerated drivers in Germany and Austria. Significantly lower rates are in the Czech Republic and Slovakia, where they are below $5 € /$ hour. In several countries, drivers are not remunerated with $€ /$ hour, but with monthly wages. The highest average wage for drivers is in Luxembourg, Germany and the Netherlands and it is above $2000 € /$ month.

Table 1 Remuneration of drivers in international road transport. Source: [11]

\begin{tabular}{lccc}
\hline Country & Wage $(\boldsymbol{\epsilon} / \mathbf{h})$ & Wage $(\boldsymbol{€} / \mathbf{k m})$ & Wage $(\boldsymbol{€} / \mathbf{m o n t h})$ \\
\hline Germany & 12.875 & - & 2347 \\
\hline Austria & 10.33 & - & 1633 \\
\hline Belgium & - & - & 1605 \\
\hline Denmark & & - & 1600 \\
\hline Netherlands & - & - & 2100 \\
\hline Luxemburg & 15.875 & - & 2381 \\
\hline Italy & - & 0.15 & 1516 \\
\hline Czech Republic & 3.77 & 0.083 & 1115 \\
\hline Poland & - & 0.08 & 1400 \\
\hline Slovakia & 4.33 & 0.131 & 1282 \\
\hline
\end{tabular}


If we compare a wage with an average wage in a particular country, it can be stated that the occupation of a road transport driver reaches the above-average level in the Central and Eastern EU countries (Fig. 1). In the Czech Republic, Poland and Slovakia, drivers' wages are higher than the average wage in these countries. For Western EU countries, the level of wages in road transport is below the average wage in that country, despite the fact that it is higher in absolute terms compared to the wages of drivers in the central and eastern parts of the EU. Therefore, it can be expected that in the western part of the EU drivers are less interested in this profession, and companies are often looking for workers from the eastern part of the EU or from outside the EU. In Western European countries, the driver's remuneration reaches hardly $60 \%$ of the average wage in a particular country.

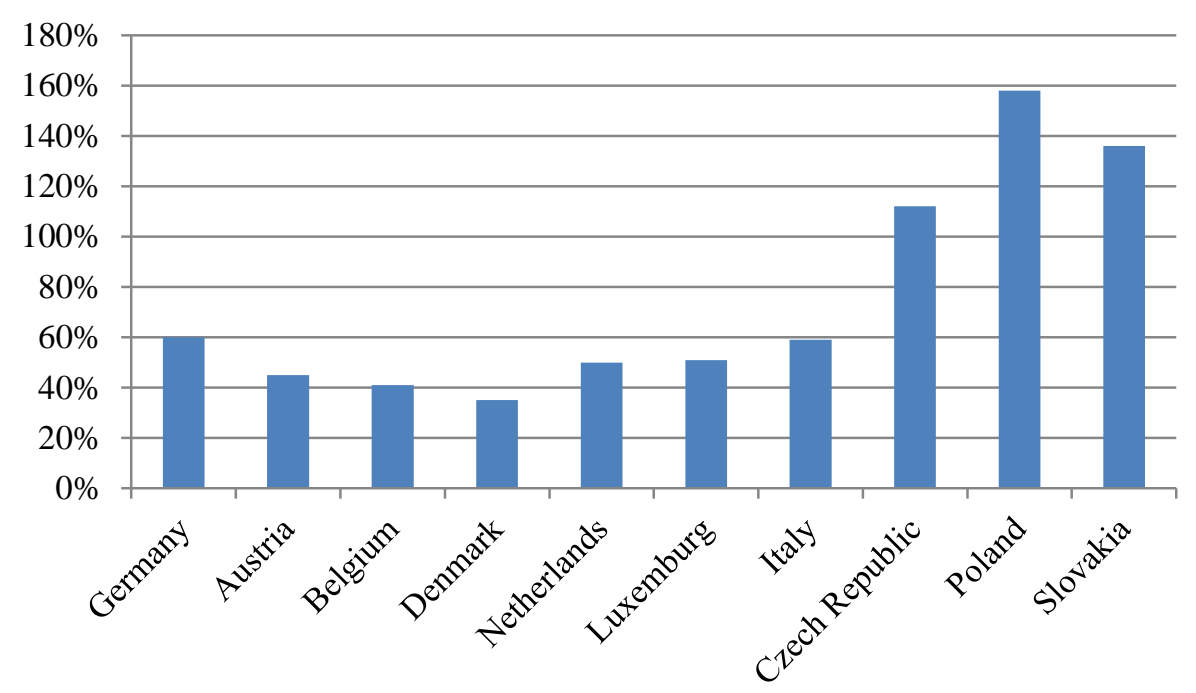

Fig. 1 The share of wages achieved by drivers at the minimum wage in individual countries. Source: authors

In analysis of a driver's wage in relation to the minimum wage, it is not possible to elaborate comparison in each country, since in Austria, Denmark and Italy the minimum wage is not the legal norm (in Austria since January 1, 2017 it is required to follow the minimum wage laid down by the collegiate body and it is expressed in $€ /$ hour). The average wage of drivers in individual countries reaches the required minimum wage level, but it is above $250 \%$ of the minimum wage in the countries of the Central and Eastern European Union, with a range of $105 \%$ to $158 \%$ in the western part of the European Union (Fig. 2). 


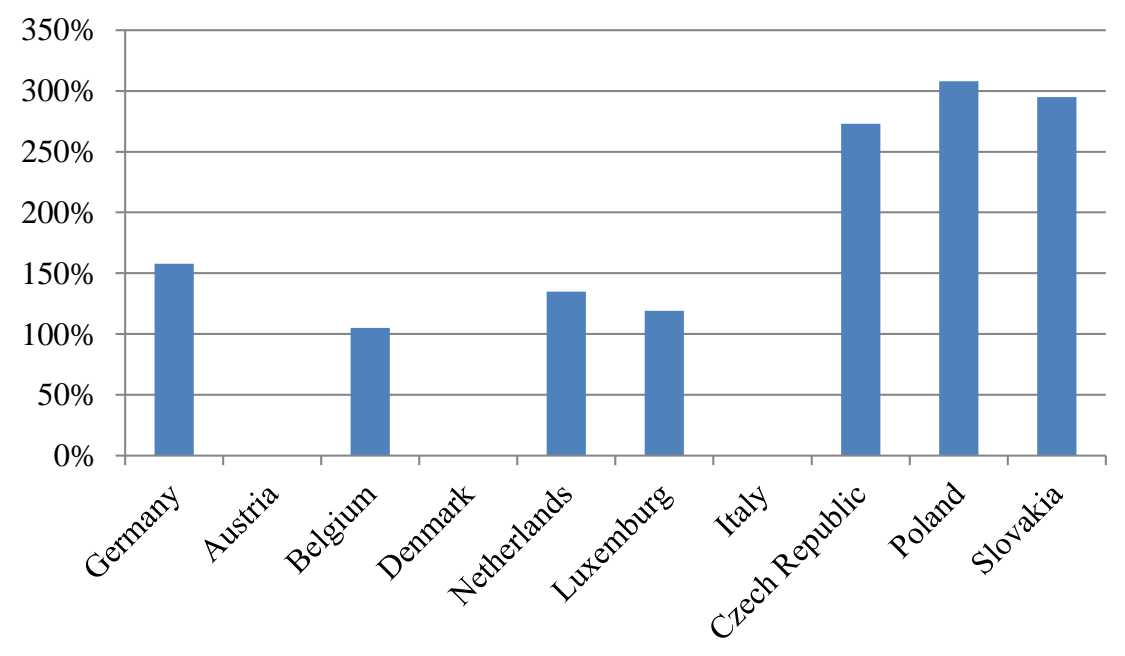

Fig. 2 The share of wages achieved by drivers at the average wage in individual countries. Source: authors

The research of drivers' remuneration also pointed to the fact that in the countries of the Central and Eastern part of the European Union, even in Italy, drivers are often rewarded in contravenes the principles of remuneration. Concerning the road transport, driver cannot be motivated with wage to perform more because such remuneration reduces road safety. This requirement is defined throughout the EU by Regulation (EC) 561/2006. Nevertheless, at the present time, there is a significant part of drivers whose wages depend on the distance travelled using a wage rate of 0.08 $0.15 € / \mathrm{km}$. According to the results of research, drivers are willing to accept this form of remuneration because the wage per month achieved with sufficient driving performance is above the average wage in the economy.

Harmonization of wages of international road transport drivers is problematic. For the countries of Western Europe, it is not possible to reduce the wage because it is already below the average wage. On the other hand, for the countries of the eastern and the middle part of the EU, it is not bearable to raise wages because nowadays they are significantly above the average wage.

In relation to the harmonization of conditions, it must be noted that the EU institutions do not have their own means of enforcing EU legislation. For example, there is no pan-European labor inspectorate. The principle of subsidiarity applies to: work and the privilege of enforcing legislation is a matter for member states. The EU therefore depends on the willingness of national governments of individual states [12]. The issue of minimum wage in the road transport sector is partly similar to the taxation of corporation tax.

According to neoclassical standard tax competition models, political leaders have repeatedly argued that globalization could lead to a destructive competition that would lead to "bottom-line" 
tax rates and would result in insufficient financial support from public institutions. Similarly, it would lead to destruction in the case of a significant increase in minimum wage only for the profession of truck drivers above the level of other professions in the country. Current developments in the countries of the Central and Eastern part of the EU make towards this fact. Reducing the minimum wage in the Western European countries would dismantle the market with a significant shortage of drivers who already have to be acquired by companies from other states in the current situation [13-16].

\section{Discussion}

The problems in road freight transport market arise because of the unequal tax burden and the different levels of average wages across EU Member States. The European Union seeks to remove barriers to market access and to harmonize common rules on road transport business. To ensure the functioning of the single market in road transport, it is necessary:

- to create a balance between social protection for drivers and the freedom of operators to provide cross-border services and to discourage excessive regulatory measures that impede the proper functioning of the single market;

- clarify and simplify existing legislation and ensure uniform implementation and enforcement in the Member States with the ultimate objective of achieving a better functioning internal market and benefits for the European economy and the Community as a whole (not only for selected Member States);

- avoid excessive administrative burdens for operators from other countries of the European Union.

\section{Conclusion}

This contribution contributes to filling the gap in understanding of social harmonization in road transport. Road transport is specific as a service because it provides the transport across the EU but it is subject to national regulations of a particular state of corporate seat. Since 2012 there is a harmonized market access for road transport. Only a person who meets the requirements of the EU regulations can provide the transport of persons or goods. At present, there is no EU member state in which access to the EU market can be achieved on simpler terms.

An ongoing problem is the harmonization of conditions of road transport business in the EU common market. The carriers from eastern and central parts of the EU operate at lower wage costs in the same transport market than other EU countries. The contribution identifies the differences in social sphere of drivers and points to the fact that in the western part of the EU, the driver's occupation is considerably lower remunerated in relation to average wage than in the EU's central 
and eastern parts despite the fact that in absolute terms the wages in western part of the EU are significantly higher. An inability to harmonize social policy in road transport business is solved by an effort of some states to introduce mandatory minimum wage for all drivers in international road freight transport. The contribution indicates a possible market distortion if such a procedure would be applied.

\section{Acknowledgments}

The contribution was elaborated with the support of the Ministry of Education of the Slovak Republic VEGA no. 1/0143/17 POLIAK, M.: Increasing the competitiveness of Slovak carriers providing road transport services in the common market of the European Union.

\section{References}

[1] Hilal, N. (2007). L'eurosyndicalisme par l'action. Cheminots et routiers en Europe. Paris: L'Harmattan.

[2] Poliak, M., Krizanova, A., Semanova, S. \& Stefanikova, L. (2013). The impact of procurement method of the transport services to the financial requirement of performance contracting entity. Transport Problems, 8(4), 67-76.

[3] Poliak, M., Komackova, L., Semanova S., Hernandez, S. \& Jaskiewicz, M. (2016). Defining the influence of the support of bus service on road safety. Communications, 18(2), 83-87.

[4] Grand, L. \& Duret, B. (2000). Différentiels de compétitivité et délocalisation des entreprises européennes de transport de marchandises. Transports, 400(March-April), 99.

[5] Poliak, M., Semanova, S. \& Poliakova, A. (2015). Risk allocation in transport public service contracts. Ekonomski Pregled, 66(4), 384-403.

[6] Dorčák, P. \& Pollák F. (2011). Analysis of Success Factors of Businesses on the Slovak Market. Logi, 2(2), 14-26.

[7] Poliak, M. (2011). Podnikanie v zasielatel'stve a v cestnej doprave. Žilina: EDIS, Slovak Republic.

[8] Dobias, G. (1993). La situation économique et sociale du transport routier de marchandises. Commissariat général du Plan. Paris.

[9] CEMT (2002). Le Dumping Social dans l'Espace Couvert par la CEMT: Application au Cas du Transport Routier de Marchandises. Paris: OCDE. 
[10] Cyprich, O., Konečný, V. \& Kilianova, K. (2013). Short-term passenger demand forecasting using univariate time series theory. Promet - Traffic \& Transportation, 25(6), 533-541. DOI: 10.7307/ptt.v2516.338.

[11] Dzuracká K. \& Poliak, M. (supervisor) (2017). Thesis. Analysis of drivers remuneration in road freight transport. University of Zilina, Slovak Republic.

[12] Jachia, E. (2017). Urban-Rural Partnerships in Peri-Urban Areas: The Role of Non-profit Organizations. Peri-Urban Areas and Food-Energy-Water Nexus: Sustainability and Resilience Strategies in the Age of Climate Change, Book Series: Springer Tracts in Civil Engineering, 111-115. DOI: 10.1007/978-3-319-41022-7_14.

[13] Farokhi, F. \& Johansson, K.H. (2015). A Study of Truck Platooning Incentives Using a Congestion Game. IEEE Transactions on Intelligent Transportation Systems, 16(2), 581-595. DOI: 10.1109/TITS.2014.2329317.

[14] Jacobsen, M.R. (2013). Fuel Economy and Safety: The Influences of Vehicle Class and Driver Behavior. American Economic Journal - Applied Economics, 5(3), 1-26. DOI: 10.1257/app.5.3.1.

[15] Arrunada, B., Gonzalez-Diaz, M. \& Fernandez, A. (2002). Determinants of organizational form: transaction costs and institutions in the European trucking industry. In Conference held in honor of Oliver E Williamsons 70th Birthday, 26. October (pp. 867-882). Berkeley, CA. Industrial and Corporate Change, 13(6). DOI: 10.1093/icc/dth033.

[16] Moreno-Monroy, A.I. \& Posada, H.M. (2018). The effect of commuting costs and transport subsidies on informality rates. Journal of Development Economics, 130, 99-112. DOI: 10.1016/j.jdeveco.2017.09.004. 